\title{
Averçenko'nun "Kara Güç" Adlı Eserinde Anlatım Gücü Olarak Semboller ve Retorik Figürlerin Analizi
}

\section{Analysis of Symbols and Rhetorical Figures as an Expression of Power in the Work of Averchenko "Black Power"}

\section{Leyla Çiğdem Dalkılıç*}

\begin{abstract}
Öz
Üslup bir yazarın eserinde bir durum ya da olaya ilişkin duygu ve düşünceleri kısacası kendini okuyucuya yansıttığı en güçlü silahtır. Yazar iletmek istediği duygu ve düşüncelerini bu araç sayesinde ortaya koyarak fark yaratır. Yazarın dili kullanış biçimi, eserlerinde yer verdiği dil birimleri eserin üslubunu belirler ve yazarın kelimeler aracılığı ile esas anlatmak istediklerinin özünü oluşturur. Bu bakımdan bir yazarın eserinde kullandığı ifade araçları yazarın üslup özelliğini ortaya çıkartır. Rus mizah yazarı Arkadi Averçenko'nun da kendine has üslubu "Kara Güç” adlı eserinde ayrı bir yere sahiptir. Hiciv, mizah ve grotesk unsurlarını eserlerinde etkin kullanan yazarın bu eserindeki üslup özelliğinin en belirgin öğeleri anlatım gücünü yansıtan semboller ve retorik figürlerdir. Diyalog tarzı anlatım tekniği ile okuyucuyu hemen eserin içine çekmek isteyen yazar, anlatımdaki ustalığını kurgu aktarımı esnasında kullandığı edebi semboller ve retorik figürlerle zenginleştirmektedir. Bu çalışmada amaç, Rus edebiyat1nın mizah ustası olan Arkadi Averçenko'nun "Kara Güç” adlı eserinde sembollerin ve retorik figürlerden benzetme ve canlandırma söz sanatları incelenerek yazarın anlatım gücünün analiz edilmesidir.
\end{abstract}

Anahtar sözcükler: üslûp, stilistik, sembol, retorik figürler, benzetme

* Dr. Öğr. Üyesi. Ankara Üniversitesi, DTCF Rus Dili ve Edebiyatı Bölümü. lcdalkilic@ankara.edu.tr 


\begin{abstract}
Style is the most powerful weapon that a writer uses in his work to reflect to readers his feelings and thoughts about a situation or event. The author makes a difference by putting the emotions and thoughts which he wants to convey through this tool. The manner in which the author uses the language and the language units in his works determines the style of his work. Also, it is the essence of what the author wants to tell us through the words. In this respect, the expression tools that an author uses in his work reveal the author's style. The Russian humorist Arkadi Avercheno has a distinctive style in his work called "Black power". He effectively applied satirical, humor and grotesque elements in his work. The most prominent elements of the stylistic feature of his works are the symbols and rhetorical figures reflecting the power of his expression. The author wants to draw the reader into his work with a dialogue style of expressive technique. He enriches his expressive mastery with literary symbols and rhetorical figures used during editing. The aim of this study is to analyze the humor of the master of Russian literarture Arkadi Averchenko, and the expressive power in his work "Black power" by examining the symbols and rhetorical figures of comparison and personification.
\end{abstract}

Keywords: style, stylistics, symbol, rhetorical figures, similitude

\title{
Giriş
}

Bir yazarın eserinde dili kullanış biçimi, ortaya konan eserin özünün anlaşılmasında kilit role sahiptir. Bu kilit rollerin anahtarı görevindeki temel dil birimlerini ise kelimeler oluşturmaktadır. Bir yazarın eserine ilişkin yapılacak dil incelemelerinde önemli bir yere sahip olan bu dil birimleri aslında eserin üslubunu belirleyen, yazarın kelimeler arac1lığıyla asıl anlatmak istediklerinin özünü oluşturan yapılardır. Bu bakımdan, bir eserde yazarın kullandığı kelimeler yazarın üslup özelliğini ortaya çıkartır. Diğer bir deyişıe, eserleri aracılıyla yazar dile yönelik bireysel kullanım gücünü yansıtır. Hayatın çeşitli alanlarında geniş bir yer tutan üslup, geçmişten günümüze kadar gelişerek şekillenen etkili ve ikna edici konuşma sanatlarının dil ve edebiyat araştırmalarında ele alınmaya başlamasıyla yeni bir boyut kazanmıştır. "Üslup", "stil”, "tarz" gibi çeşitli şekillerde ifade edilebilen bu terim, zamanla bir bilim alanı haline gelmiş üslupbilim, üslup bilimi, biçem bilim, deyiş bilim, anlatımbilim, stilistik gibi çeşitli terimlerle Türkçeye girmiştir. $\mathrm{Bu}$ çalışmada ise stilistik terimi tercih edilmektedir.

Stilistik terimi Batı literatüründe "yazılı ve sözlü dili ürünlerinin üslubunu araştırıp özelliklerini ortaya çıkarma ve (veya) iyi ve doğru üslupla yazmak, konuşmak için yol gösterme amacını taşıyan uzmanlık dalına verilen isimdir" (Aytaç, 2009, s. 77). Stilistik geniş bir alana yayılmış ve kesin kalıplara konulması güç bir alan olarak karşımıza çıkmaktadır. Bir diğer değişle üslubun doğrudan dilbilimini mi yoksa edebiyatı mı ilgilendirdiği tartışmalıdır. Stilistiğin tanımına ilişkin yapılan bazı betimlemelere bakacak olursak bu kavramın hem dilbilimde, özellikle de uygulamalı dilbilimde, hem de edebiyat alanında yer aldığını görebiliriz. Dilbiliminde stilistiğin ne olduğuna ilişkin 
tanımlamalara bakarsak stilistik, dili tarihsel gelişimi içerisinde tüm kısımları ile birlikte ele alan dili ve yapısını tüm ayrıntısı ile inceleyen bir bilim dalıdır (Vinokur, 1959, s. 223). Başka bir tanıma göre ise stilistik, söylemin içeriği, amacı, iletişimin alanı ve durumuna bağlı olarak metindeki dil birimlerinin uygun bir şekilde kullanılmasını ön gören dil sisteminin farklı seviyelerinin ifade özellikleri ile araçlarını inceleyen bir bilim dalı şeklinde ifade edilmektedir (Kojina vd., 2014, s.34). Böylelikle, dilbilim çerçevesi içerisinde stilistik genel anlamda hem dildeki etkili dil araçlarını incelemekte hem de iletişim esnasında ortaya çıkan çeşitli dil araçlarını dildeki işlevsellikleri açısından inceleyen bir bilim dalı olarak karşımıza çıkmaktadır. Edebiyatta stilistiğin nasıl ele alındığına ilişkin çalışmalara baktığımızda ise stilistiğin daha çok yazarın üslubu ile ilintili olduğunu görürüz. Bu bakımdan, edebiyat alanında stilistik daha çok yazarın çeşitli dil öğelerini nasıl kullandığını ve onları bir araya getirirken metni nasıl oluşturduğunu anlama amacı güder. Bu bağlamda edebiyatta stilistiğin üslup ve metin bütünlüğü açısından ele alınması daha ön plandadır: üslup, "belli bir duyuş, görüş ve birikime sahip olan sanatçının hayatı boyunca edindiği tecrübe ve tavırlarla seçtiği konuyu, biçim ve içeriğin belirlediği vasıta ve yöntemler kullanarak kendisine has bir biçimde ördüğü kelimelerle anlatmasından doğan bir edebi değer unsuru ve ölçüsüdür” (Çoban, 2004, s. 10) Edebi eserin sahip olduğu metnin özelliğinin anlaşılabilmesi için ise, metnin üslup bakımından değerlendirmesi önemlidir. Bir edebi eser metni, üslup etkisi bakımından ele alınmalı, yazarın ve dönemin öteki eserleri ile bağlantı kurulmalı, eserler estetiksel açıdan değerlendirilmeli ve eleştirsel yorumlanmalıdır (B. Spillner, akt. Aytaç, 2009, s. 77). Bu bakımdan Bally, stilin, ya da üslubun, insanın kendisini yansıttığını belirterek, bir kişinin iletişim sırasında çeşitli etkenler doğrultusunda kullandığı dil ile bir yazar veya şairin edebi eserlerinde kullandığı dili birbirinden tamamen ayırmak gerektiğini savunmuştur: "Altını çizmek gerekir ki, belirtilen ifade, stil incelemelerinde mesela, Balzac'1n stil incelemesinde, sanki Balzac'in bireysel tarz incelemesi yapıldığı düşüncesine itebilir. Bu ise büyük bir hatadır. Toplumun tüm kesimi için ortak olan günlük hayattaki konuşma ile bir şairin, yazarın ya da konuşmacının dili kullanımında büyük bir uçurum bulunmaktadır" (Bally, 2001, s. 36).

Böylece stilistik konusuna ilişkin iki ayrı bakış açısı olduğu ve engin bir konu alanını kapsadığı görülebilir. Her iki bilim dalının stilistiği ele alış biçimlerindeki ağırlık merkezleri farklıdır. Araştırmamızın bundan sonraki kısmında, çalışmamızın amacını oluşturan Rus yazar Arkadi Averçenko'nun göçmeden önce vatanı Sivastopol'de basılan son eseri olan ve Türkçeye "Kara Güç" olarak çevrilen, "Neçistaya sila" (Нечистая сила) adlı eserin üslupsal özelliklerini zenginleştiren sembollerin ve retorik figürlerin incelemesine geçilecektir. İnceleme kısmına geçmeden önce yazarın üslubu ve anlatım gücüne ilişkin birkaç noktaya değinmekte fayda vardır.

\section{Averçenko'nun üslubu ve anlatım gücü}

Üslubu belirli kılan şey biçime dayalı ifadesidir. İfadede yer alan kelimelerin hem tek 
başlarına hem de metin içerisinde taşıdıkları anlam ve çağrışım ilişkileri, aktarılış biçimi ve kullanımdaki amaçları üslubun metnin içeriği ile olan ilişkisine işaret etmektedir. Dilin mecazi gücünü, renk ve eylem zenginliğini, kısacası dilin anlatım dağarcığını kişisel becerileriyle bir nevi söze ya da yazıya döken böylece dile canlılık kazandıran üslup, Rus yazar A. Averçenko'nun eserlerinde ayrı bir yere sahiptir (Tekin, 2002, s. 168). A. Averçenko eserlerinde kendine has bir üslupla ortaya çıkarak, anlatımda grotesk unsurlara geniş bir yer vermektedir. Yazar özellikle güldürü unsurunu sıklıkla kullandığı eserlerinde özellikle de devrim sonrasında hiciv ve groteskle harmanlayarak trajik olayları gülünç durumlarla daha da trajik bir hale getirmektedir (Levistki, 1999, s. 332-333, Kuçeryavıh, 2018, s. 198-200). Grotesk, okuyucuyu giderek dünyaya yabancılaştıran ve onu eğlenceli hayali bir alana götüren, içinde esrarengiz, tekin olmayan güçlerin egemenliğinin yansıdığı, trajikle komiklik, adilikle yücelik gibi aslında bir araya gelmez gibi görünen şeylerin bir oyun havasında birleştirildiği, biçimsizliğin biçimi, tabiata aykırılığın tabiiliğidir (Aytaç, 2009, s. 342). N. Ünlüaycıl'a göre, groteskin temelinde kendisini çevreleyen dünyanın dehşeti altında ezilen ve bu dünyanın dehşet dolu bir dünya olduğunu fark eden "gören adam" bulunmaktadır. Gören adam, kendisi için yabancılaşmış dünyaya farklı bir pencereden bakmaktadır (Ünlüaycıl, 2003, s. 70). A. Averçenko da Devrim sonrasında ülkesinde yaşanan gelişmelere farklı bir pencereden bakmaktadır. Yazar kişisel penceresinden gözlemlediği olayların kendince ne kadar absürt olduğunu etkili bir biçimde ortaya koymak adına ise grotesk sanatına yönelmiştir. Yazar kimi zaman bizzat yaşayıp tecrübe ettiği kimi zamanda duyduğu ya da tanık olduğu olayları eserlerine yansıtabilmek adına hiciv ve grotesk sanatını harmanlayarak gerçek ile kurguyu birbirine karıştırıp okuyucuya sunmaktadır. Gerçek olan olayları, olması imkansız görünen olaylarla daha da etkili bir hale sokabilmek için ise, her bir hikayenin baş rolünde bulunan, ancak sürekli olarak değişen, farklı kahramanlar kullanmaktadır. Bu kahramanların hepsi Rus toplumunun bir parçasını oluşturan kişilerden oluşmaktadır: at arabası sürücüsü, ağaçların altında kitap okuyan sarı örgülü saçlı, mavi gözlü Rus kızı, evinde piyano çalan sanatçı, ayakkabı tamircisi, saraciye ustası, pazarc1, papaz vs. Bu, yazarın her bir hikayesinde ortaya çıkan farklı karakterler ve hikayeler yardımıyla Devrimin etkilerinin toplumun her kesimini nasıl farklı açılardan etkilediğini kısa fakat öz bir biçimde ortaya koyma yöntemidir. Yazar Devrimin kendisinde ve yine kendisine göre Rus toplumunda uyandırdığı olumsuz izleri etkili bir biçimde okuyucuya aktarmak adına doğrudan olaya geçiş yapmakta ve yine absürt bir son ile hikayelerini bitirmektedir. Burada amaç okuyucunun biran önce konunun içeriğine sokulması ve hikaye sonunda kendi çıkarımını yapmasıdır. Gülünç bir biçimde dile getirilen olaylar, A. Averçenko için, Devrimin tahribatını okuyucuya ters bir etki yaparak aktardığı en önemli araçlar olarak okuyucunun karşısına çıkmaktadır. A. Averçenko'nun "Kara güç" eseri de dahil olmak üzere, seçmiş olduğu anlatım teknikleri de eserlerindekianlatımı etkilikılmaktadır.Anlatımteknikleriarasındayazarın ençoktercih ettiği ise diyalogdur. Hemen hemen anlatı türlerinin hepsinde kullanılan diyalog tekniği ile yazar okuyucuyu doğrudan doğruya kahramanlarla ve hikâyede anlatılan kurguyla buluş- 
turmaktadır. Böylelikleanlatılmakistenenkısa fakatözveetkilibirbiçimdeaktarılmaktadır. A. Averçenko'nun anlatım gücü işte buradan gelmektedir. Anlatım gücündeki bir diğer ustalığ ${ }_{1}$ ise kurgu aktarımı esnasında kullandığı edebi semboller ve retorik figürlerdir. Çalışmanın bundan sonraki kısmında yazarın "Kara Güç” adlı hikayesinde kullandığı semboller ve retorik figürler incelenecektir.

\section{Kara Güç'te semboller ve retorik figürler}

\subsection{Semboller}

Yazar algıladığı dünyaya ilişkin görüşlerini eserlerinde yansıtırken bunu estetik kayg1 anlayışıyla en iyi biçimde sunmaya çalışır. Bunu yaparken de edebi imgelerden ve çeşitli sembollerden yararlanır. İmge kavramı, hem eserin tümünü kapsayabileceği gibi, bir şehir, köy, ülke gibi eserin belirli parçasını da içine alabilir. Sembol (simge) ise, üzerine soyut bir anlam, bir düşünce yüklenmiş somut bir kavramdır. Bu kavramın anlamını tek bir ifade ile dile getirmek mümkün değildir, çünkü bu kavram aracılığı ile ortaya konan belirli duygu ve düşünceyi sembolden ayrı tutarak açıklamak mümkün değildir (Kirillina, 2011, s. 6-7). "İmge bir tasarım iken, sembol bir timsaldir”. Sembolde göstergenin anlamı başka bir göstergeye yüklenerek verilirken, imgede göstergeden daha çok sunulmak, yansıtılmak, aktarılmak istenen anlam ve anlamlandırmanın taşınması söz konusudur. Bu nedenle imge, kurulmuş göstergeler dizgesinin bütününden doğar, dolayısıyla bir imge içinde bir veya birden çok sembolü barındırabilir, ancak sembol imgeye dönüşüp imge olarak tanımlanmaz (Durmuş, 2011, s. 747) A. Averçenko "Kara Güç” adlı eserine yolculuk yapmakta olan yorgun bir yolcunun etrafta kötü bir üne sahip bir şatoda gecelemek durumunda kalması ile başlamaktadır. Kendisine yapılan uyarılara aldırış etmeden yarı harabe durumundaki şatoda geceyi geçirip dinlenmek isteyen yolcu, birden etrafının korkunç yaratıklarla sarıp sarmalandığını fark eder, korkudan öleceğini düşünürken ansızın gecenin karanlığında bir kurtarıcı edası ile sesi yankılanan horozun ötüşü ile etrafını saran kötülüklerden kurtulur. Yazar bundan sonra Devrim öncesi ve Devrim sonrası Rusya'yı eserinde sunduğu farklı başlıklarla okuyucuya aktarmaya başlamaktadır. Böylelikle yazar aslında Devrimin Rusya için ne kadar büyük yıkım ve felaketler getirdiğini anlatmak istemekte, Devrim öncesi Rusya'nın ise tüm geleneklerini ve toprak bütünlüğünü korumuş olan gerçek bir ev olarak ortaya koymaktadır. İyi ve kötü, eski ve yeninin savaşı şeklinde cereyan eden olaylar Devrim sonrası Rusya imgesi ile belirginlik kazanmaktadır. Devrim sonrası Rusya imgesi iyi ve kötü olmak üzere iki belirgin sembolle başlamaktadır. Yazar eserine adını verdiği "Kara gücü” yani kötüyü Devrimle ilgili olan her şey ile ilişkilendirirken, iyiyi ise Rusya'nın geçmişinde ve Rusya'nın bu kara güçten kurtuluşunda görmektedir.

\section{3. İyi ve kötünün sembolü: Horoz ve kötü güçler}

Yazar hikâyesine, yolculuktan yorulmuş bir yolcunun dinlenmek için harabe duru- 
mundaki bir şatoya girmesi ve geceyi geçirirken uyuduğu sırada etrafını korkunç yaratıkların sarması ile başlar.

3.а.) “Завернулся усталый путник в свой плащ, лег - и пошло тут такое, от чего волосы наутро делаются белыми, взгляд надолго застывает стеклянным ужасом... Много всякого выползло, вышагнуло, выпрыгнуло и закружилось около путника в безумном хороводе: незакопанные покойники с веревкой на шее, вурдалаки, нежить разносортная, синие некрещеные младенцы с огромными водяночными головами и тонкими цепкими лапками, похожие на пауков, - шишиги, упыри, чиганашки - все, что неразборчивая и небрезгливая ночь скрывает в своих темных складках" (Averçenko, 1992, s. 272). Çev.: "Yorgun yolcu paltosuna sarınır ve yatar. Fakat sonrasında, sabaha insanın saçlarını beyazlatacak, bakışlarını uzun bir süreliğine korkunç bir donukluk kaplayacak öyle bir şey olur kiOradan buradan bir sürü şeyler belirmeye, karşısına çıkmaya ve çılgın bir dansla yolcunun etrafinda dönmeye başlar: boyunları iple sarılı, gömülmemiş ölüler, hayaletler, türlü türlü yaratıklar, ince ama yine de kuvvetli pençelere sahip, vaftiz olmamış, mavi renge dönüşmüş, kafaları ödemli bebekler, örümceğe benzeyen gulyabaniler, vampirler... Anlaşılmaz ve korkutucu gecenin, karanlı̆̆ı içinde sakladığı tüm yaratıklar...” (Averçenko, 2017, s. 167).

Yazar, Devrimden sonra ülkede kol gezen güçleri, Kızıl Ordu mensuplarının, yöneticilerin, Devrimi destekleyenlerin özelliklerini insan dışı varlıklarla karakterize etmekte ve insanı korkutan, saçlarını ağartacak, neredeyse ölümüne neden olacak bu tip kişileri ölüler, hayaletler, yaratıklar, vampirler gibi çeşitli ifadelerle aktarmaktadır. Böylece yazar, Devrimi kötülügün temsilcisi, Devrim yanlılarını da insanlıktan uzak varlıklar olarak görmektedir. Yazar, bu kötülüğün ilelebet devam etmeyeceğini, iyiliğin galip geleceğini ise hikâyesinde yer verdiği horoz sembolü ile aktarmaktadır.

3.b) “...Но чу! Что это? В самый последний, в предсмертный момент вдруг раздался крик петуха - предвестника зари, света, солнца и радости” (Averçenko, 1992: 272). Çev.:“... O da ne? Ölüm öncesi o son anda, aydınlığın, 1şı̆̆ın, güneşin ve sevincin habercisi horozun sesi ansızın yankılanıverir." (Averçenko, 2017, s. 167-168).

Kötü güçler olarak aktarılan yaratıklar bir nevi Kızıl Orduyu, horozun sesi ve kendisi ise, yazarın o bildiği eski, iyi, alış1lmış Rusya'ya götürecek olan, kurtuluşun simgesi Beyaz orduyu temsil etmektedir.

3.c) Слабый это крик, еле слышный - и куда что девалось: заметалась, зашелестела вся нечисть, вся нежить, запищала последним писком и скрылась - кто куда А свет разгорается все больше и больше, а петух поет все громче и громче... Здравствуй, милый петух! (Averçenko, 1992, 272-273). Çev.:“Zar zor duyulan cılız sesle birlikte tüm o yaratıklar, kötü güçler etrafta kaçışıp dağılmaya başlar, son bir ötüş ile de ortadan kaybolurlar. Güneş gittikçe daha çok parlarken horoz da gittikçe daha yüksek bir sesle öter ... Selam olsun sana güzel horoz!” (Averçenko, 2017, s. 168).

Güneşin doğuşunun habercisi olan horoz, Rus halk biliminde ve Rus edebiyatında sık- 
ça karşılaşılan bir imgedir. Rus edebiyatında ve halk masallarında genel olarak iki şekilde ortaya çıkmaktadır. Birincisi, horoz bir yandan, zayıf, aklı bir karış havada, söz dinlemez bir karakter olarak tasvir edilir ${ }^{1}$. İkincisi, horoz cesur, korkusuz, arkadaşlarının yardımına koşan bir kahraman, akıllı, doğaüstü güçlere sahip bir figür olarak karşımıza çıkar². N. Gogol A. Kuprin, M. Bulgakov gibi Rus yazarların eserlerinde horozun ötüşünün kötü güçleri kovucu bir etkisi vardır³ . Averçenko, bu eserinde iyiliğin simgesi horozu, yukarıda verilen ikinci anlamda ele almaktadır. Bunu yaparken de özellikle "Rus horozu" ifadesini diğer "horoz" kavramlarından kesin bir şekilde ayırarak "Rus horozunu" simgeleştirmektedir.

3.d.)“Это не тот страшный «красный петух”, что прогулялся по России от края до края и спалил все живое, это не изысканный галльский шантеклер, возвещающий зарю только в том случае, если ему будут уплачены проценты по займам и признаны все долги; это и не тот петух, после пения которого ученик трижды отрекся от своего Божественного Учителя. Нет, это наш обыкновенный честный русский петух, который бодро и весело орет, приветствуя зарю и забивая своим простодушным криком осиновый кол в разыгравшуюся в ночи нечистую силу” (Averçenko, 1992, s. 273). Çev.: “Bu, bir uçtan bir uca tüm Rusya'yı dolaşan ve önüne çıkan tüm canlıları yakıp yıkarak yok eden ne o korkunç "kızıl horoz"; ne şafağı, yalnızca kredi faizlerinin ödenmesi ve tüm borçların kabul edilmesi durumunda müjdeleyen o zarif Galya horozu; ne de ötüşünü duyduktan sonra ilahi öğretmenini üç kez inkar eden öğrencinin duyduğu o horozdur. Hayır! Bu, şafağı selamlayarak içten ötüşüyle geceleyin ortaya çıkan kötü gücü kovalayan, canlı ve neşeli bir şekilde öten bizim bildiğimiz dürüst Rus horozumuzdur" (Averçenko, 2017, s. 168).

Yazar, bu horozun "iyi, dürüst Rus horozu” olduğunu kötülüğü temsil eden üç ayrı horoz sembolü ile ayırmaktadır. Birincisi, bir uçtan bir uca tüm Rusya’yı dolaşarak önüne çıkan tüm canlıları yakıp yıkarak yok ettiğinden bahseden "kızıl horoz" olarak ifade ettiği "Kızıl Ordudur"; ikincisi Fransa'nın alegorik isimlerinden biri olan ve aynı zamanda Fransa'nın resmi olmayan milli sembolünü teşkil eden "Galya horozu”; üçüncüsü ise, İncil'e göre, Hz. İsa'nın öğrencisi olan Petrus'un, kendisini tanıyan ve suçlayan hizmetkârından korkarak üç kere İsa'yı inkâr ettiği sırada öten horozdur. Horoz'un ötüşü, Petrus'a "horoz iki kere ötmeden beni üç kere inkâr edeceksin” diyen Hz. İsa'nın sözlerini hatırlatmış ve Petrus pişmanlıktan ağlamıştır. Yazar bir yandan, "kızıl horoz", “zarif Galya horozu” ve "öğretmenini üç kez inkâr eden öğrencinin duyduğu horoz” ifadeleriyle metafor yaparak ilkinde horozun kızılımsı-kahve rengini Kızıl Ordu; eskiden Galyalılara ait olan Galya topraklarını Fransa ve dini metin içerisinde geçen horozu ise kötü ahlakın temsili inkâr ile özdeşleştirmiştir. Bu ifadelerde metaforların yanı sıra yeniden adlandırmaların da iç içe geçtiği söylenebilir, söz gelimi, Kızıl Ordu yerine Kızıl horoz; Fransa yerine Galya horozu ifadelerinin kullanımı buna örnek olarak gösterilebilir. Yukarıdaki örneklerde sunulan üç horoz simgesinin ortak noktası kötülüğü sembolize etmeleridir. Yazar "bizim dürüst Rus horozumuz" ifadesini ise kurtarıcı Beyaz ordu ile 
eşleştirerek "horoz gagasını çoktan açtı bile" ifadesiyle de zaferin yakın ve kaçınılmaz olduğunu, ülkede kol gezen tüm kötülüklerin ise yok olup gideceği mesajını okuyucuya aktarmakta yahut en azından gerçekleşmesini arzu ettiğini bu şekilde yansıtmaktadır.

3.е) "Еще клубятся повсюду синие некрещеные младенцы, вурдалаки, упыри и шишиги - но уже раскрыт клюв доброго русского петуха - вот-вот грянет победный крик его!" (Averçenko, 1992, s. 273). Çev.: "Mavi renkli, vaftiz olmamış bebekler, yaratıklar, ölüler her yerde hala kendini gösteriyor olabilirler fakat iyi Rus horozunun gagası çoktan açıldı bile! Zafer ötüşünün duyulmasına ise çok az kaldı!" (Averçenko, 2017, s. 168).

Böylelikle yazar, eserin giriş kısmında açık bir şekilde iyi ve kötü imgelerini "kötü güçler" ve "horoz" sembolleri aracıllğıyla okuyucuya aktarmakta, Rus folklorunda da olmak üzere birçok çeşitli kültürel gelenekte güneşin temsilcisi, aydınlığın simgesi olan horoz sembolünü ön plana çıkararak dolaylı olarak Kızıl Ordunun yenilmesi ve eski Rusya'ya geri dönülmesi arzusunu dile getirmektedir.

\section{Felaketin sembolü: Elma (yabloçko)}

Elma sembolü Rus edebiyatında ve folklorunda farklı anlamlarıyla karşımıza çıkmaktadır. Kimi halk masallarında gençlik ve sağlık iksiri (сказка о молодильныцх яблоках и живой воде), kimi masallarda zenginliğin sembolü (Иван-иаревич и Серый волк) olarak olumlu bir sembol biçiminde karşımıza çıkarken, kötülüğün, felaketin, acının, ölümün sembolü olarak da yer edebilmektedir. Rus mantalitesi sözlüğünde ise elma, kavga ve anlaşmazlığın nedeni olarak tasvir edilmektedir (Kolesov, 2014, s. 517).

Eserde geçen, Эх, яблочко... куда котишься?» - “elmacık nereye gidiyorsun/ nereye doğru yuvarlanıyorsun?" ifadesi "yabloçko" adlı bir Rus halk şarkısından alıntıdır. Bu ifade, Rusçada "çastuşki" olarak adlandırılan, genel olarak dörtlük formatında söylenen Rus halk şarkısı ile bu şarkının melodisi eşliğinde yerine getirilen bir denizci dansının adı için de kullanılmaktadır. Rusya'da iç savaş döneminde (1917/1918 -1922/1923) birçok farklı varyasyonu bulunan şarkı, bilhassa Ekim Devriminden sonra dörtlük olarak yaygınlık kazanmıştır.

Kızıl Ordulular, "eh elmacık nereye gidiyorsun, Beyazların eline düşer de geri gelemezsin" şeklinde; Beyaz Ordulular ise "eh elmacık nereye gidiyorsun, Kızılların eline düşer de geri gelemezsin" şeklinde şarkıyı dile getirmekteydiler". Yazarın, bilhassa bu dörtlüğü kullanmasının nedeni, ifadeyi dile getiren kahramanın ilerlediği yolun geri dönüşü olmayan, tehlikeli ve ölümcül bir yol olduğuna vurgu yapmasıdır. Örnek metinde (2. a.) ve "gitti" olarak belirtilen kelime, metaforik bir anlama sahip olup devrim sürecine girildiği ve yerine getirilen eylemlerin geri dönüşü olmayan olumsuz sonuçlar doğuracağı gibi derin bir anlam aktarmaktadır.

4.а.)“Сидел Спирька Шорник у себя в мастерской, мирно работал, никого не трогал - явились к нему: - Брось, дурак, работу - мы тебя главкомвоенмором 
сделаем. Грабь награбленное! - А ежели Бог накажет? - Эва! Да ведь Бога-то нет. - А начальство? - Раков в речке кормит. - Да как же, наша матушка Расея... - Нету матушки Расеи. Есть батюшка Интернационал. - Да ну! Комиссия отца Денисия! - Ну, брат, теперь комиссия без отца Денисия. Аки плод на древе, красуется колеблемый ветром отец Денисий. Крякнул только Спирька, натянул на лохматую голову шапчонку и, замурлыкав пророческий псалом: «Эх, яблочко... куда котишься?” - пошел служить в комиссию без отца Денисия. Покатился” (Averçenko, 1992: 279). Çev.: "Saraciye ustası Spirka atölyesinde oturuyordu. Etliye sütlüye karışmadan sessizce kendi işini yaptığı bir sırada çıkıverdiler ortaya: - Bırak çalışmayı sersem, seni Askeri Deniz Komutanlığının başına getireceğiz. Çal çalabildiğin kadar! Bunun için Tanrı cezalandırmasın sonra? - Hah, Tanrı yok ki. - Ya baştakiler? - Nehirde yengeç besliyor onlar. - Ya Vatanımız, biricik anamız Rusya? - Vatanımız, anamız Rusya yok artık, bundan böyle babamız Enternasyonal var. - E peki peder Denis'in komisyonu? - Eh kardeşim, komisyon bundan böyle peder Denis'siz. Peder Denis artık Ake ağacındaki bir meyve gibi rüzgardan sallanıyor. - Spirka çığlık atıp bir kehanet ilahisi mırıldanarak başındaki şapkasını aşağı doğru çekti: "Eh elmacık, nereye gidiyorsun" - Papaz Denis'in olmadığı komisyonda görev almaya gidiyorum” dedi - Ve gitti” (Averçenko, 2017, s. 177).

İkinci defa eserde "yabloçko" ifadesinin geçtiği yer ise, Kızıl Orduya karşı zaferin kazanılmasından sonra daha önce yitirdiği evini geri alan bir başka kahramanın apartman görevlisi ile olan diyalogunda, eserin sonunda geçmektedir. Ev sahibi evine geldiğinde, apartman görevlisi ile karşılaştır ve görevli kendisine her şeyin yerli yerinde olduğunu sadece “yabloçko” parçasının çalına çalına piyanosunun hasar gördüğünü aktarır. Söz konusu kelimenin ikinci olumsuz çağrışımı ise burada karşımıza çıkmaktadır:

4.b.)- Цела-с, пожалуйте. Комиссар тут жил - тем только и сохранили! Пианино, правду говоря, маленько «Яблочком» расшатали да абажур в гостиной разбили.. Позавчера только и бежал комиссар... Жидка Варвара на расправу!.. Вот-с ключик. (Averçenko, 1992, s. 329). Çev.: Sapasağlam duruyor. Polis şefi burada yaşadığı için bir şey olmadı! Yalnız, "Yabloçko" parçasını çala çala piyanoyu yıprattılar bir de salondaki avizeyi kırdilar. Polis şefi daha geçen gece korkusundan kaçtı.... İşte buyurun, anahtar (Averçenko, 2017, s. 255).

Edebi eserde bilinçli olarak yaratılmış olan imgeler ve buna bağlı olarak semboller, hem stilistiği (üslupbilimini) ilgilendirmekte hem de az sözle çok şey anlatma yoluna giderek yazarın dilinin anlaşılmasını sağlamaktadır. Yazarın üslubunun anlaşılmasını sağlayan bir diğer husus ise bir toplumun kültüründe yer etmiş sembollerin anlamlarının incelenmesidir. M.V. Dobrınina düşünceleri oluşturan bir araç olarak sembolün, toplumun kültürel deneyiminin geçmişle olan bağlantısını ve bu bağlantının metne olan yansımasını ortaya koymaktadır (Dobrınina, 2005, s. 3). Böylece bir topluma ait değerler bir metnin, bir diğer deyişle yazarın kendisinin anlaşılmasında etkili bir rol oynamaktadır. 


\section{Retorik figürler}

Retorik figürler ya da söz sanatları (edebi sanatlar), ifade edilmek istenen kelimelerin gerçek anlamlarının dışına çıkarak ifade edilmesidir. İfadeye zenginlik katmak, etkinliğini arttırmak, monotonluğu ortadan kaldırmak ya da az sözle çok şey ifade etmek için kullanılan retorik figürler, Rus dilinde mecaza dayalı sanatlar ve ifadeye dayalı sanatlar olmak üzere iki grupta incelenmektedir.

İfadeye dayalı sanatlar daha çok dil araçlarının stilistik açıdan kullanımlarını inceler. Bunlar, anafor ve epifor, paralelizm, karşıtllk ve oksimoron, derecelendirme, yoğunluk, eksilti, susma, retorik hitabet, retorik soru, çok bağlaçlık ve bağlaçsızlı olmak üzere sıralanmaktadırlar. Mecaza dayalı anlatım sanatları (tropeler) ise, dilsel ifadede yer alan kelime ya da söylemin gerçek anlamının dışında kullanılarak, anlatımı daha etkili kılmak ve söze canlılık kazandırmak amacıyla yapılan mecaza dayalı sanatlardır. Bunlar dilde epitet, karşılaştırma yoluyla benzetme, metafor, ad aktarmasl, sinekdoş, abartma ve litota, ironi, alegori, kişileştirme (teşhis), yeniden ifade olmak üzere on alt grupta incelenmektedir (Rozental, 2011, s. 395-406).

Çalışmanın bu kısmında ise A. Averçenko'nun eserlerindeki dili etkili kılmak ve anlatımını güçlendirmek için en çok kullandığı mecaza dayalı anlatım sanatlarına örnek olabilecek metinden parçalar incelenmiştir. Aşağıda ayrıntısıyla ele alındığı üzere, A. Averçenko'nun tropeleri sıklıkla kullandığ 1 ve bunu da bilhassa anlatımı zengin kılmaktan ziyade güçlü kılmak için yaptığı ve böylece ifadelerini daha da etkili kıldığ 1 gözlemlenebilmektedir. Sıkça kullandığı retorik figürlerin başında ise, benzetmeler gelmektedir. Benzetmelerin çoğunlukla canlandırmalar ile iç içe geçerek zenginleştirildiği gözlemlenmektedir. İncelenen benzetmeler ile yazarın kullandığı diğer retorik figürler ve aktarmak istediği düşüncelerin irdelenmeye çalışılması amaçlanmaktadır.

\section{Benzetme ve canlandırma}

Benzetme, dildeki bir varlığı bir başka varlıkla karşılaştırarak ortaya çıkarma yöntemidir. Rusçada dilde karşılaştırma yoluyla benzetme birkaç yöntem aracılloğıyla gerçekleştirilebilmektedir. Bunlar: 1) İsmin araç durumu halinin kullanılması (время летит птицей), 2) Sıfatların karşılaştırmalı yapılarının kullanılması (она красивеe всех), 3) Durum zarflarının kullanılması (по-звериному) ve 4) точно, словно, как, будто, как будто gibi karş1laştırma yoluyla benzetme ifade eden kelimelerin kullanılması ile mümkün olabilmektedir. Averçenko'nun bunun için daha çok dördüncü yöntemi tercih ettiği görülmektedir.

1) “И когда при мне какой-нибудь слащавый многодумец скажет: «Что ни говорите, а Ленин и Троцкий замечательные люди...» - мне хочется спихнуть его со стула и, дав пинка ногой в бок, вежливо согласиться с ним: “А что вы думаете! Действительно, замечательные люди! Такие же, как один из учеников Спасителя мира - тоже был замечательный человек: самого Христа предал”. Так уж если Христа, самого Бога, человек предал, то предать глупую, доверчивую Россию куда легче" (Averçenko, 1992, s. 279). Çev.: "Çokbilmiş akıllının biri yanımda "Ne derseniz 
deyin Lenin ve Troçki harika insanlardır...” dediğinde bu kişiyi sandalyeden indirip, ayağımla böğrüne bir tekme attıktan sonra kendisiyle hem fikir olduğumu nazikçe belirtesim geliyor: - Ya öyle mi! Tabii gerçekten de harika insanlar! Tıpkı evrenin kurtarıcısı İsa'nın kendisine ihanet eden öğrencilerinden biri gibiler. İnsan, eğer İsa'ya, Tanrı'nın kendisine bile ihanet edebiliyorsa her şeye inanıp kanan, saf Rusya'ya haydi haydi ihanet eder" (Averçenko, 2017, s. 178).

Örnekleme yoluyla yapılan bu benzetmede yazar Devrimin başkahramanları olan Lenin ve Troçki'yi İsa'ya ihanet eden müritlerinden birine benzeterek adı geçenleri dolaylı olarak ihanet ve vatan hainliği ile suçlamakta, bu kişilerin varlığını tehlikeli ve insan türünün en acı örneği olarak görmektedir.

2) “Григорий Недорезов был молчалив, как его старый башмак. Даже, пожалуй, еще молчаливее; башмак хоть разевал рот и настойчиво просил каши, сверкая белыми деревянными зубами, а рот Недорезова Григория был закрыт, как чемодан, от которого потеряли ключ." (Averçenko, 1992, s. 299). Çev.: “Grigori Nedorezov eskimiş olan ayakkabısı kadar sessizdi. Hatta belki de Nedorezov daha da suskundu, çünkü yırtık ayakkabısı hiç olmazsa ağzını açıyor, beyaz tahta dişlerini göstererek ısrarla yemek istiyordu. Grigori Nedorezov'un ağzı ise, kilidi kaybolmuş bir valiz gibi kapalıydı" (Averçenko, 2017, s. 210).

Buradaki benzetmede ise yazar, kahramanın suskunluğunu yani ölü halini eskimiş bir ayakkabıya ve kilidi kaybolmuş bir valize benzeterek kahramanın yaşam süresinin kullanım süresi dolmuş bir eşya gibi dolarak sonuna geldiğini belirtmektedir.

3) “Башмак, разевая рот до ушей, вопил на весь крещеный мир, требуя законной порции каши... Владелец его, наоборот, молчал как убитый (Averçenko 1992, s. 300). Çev.: Ayakkabısı kulaklarına kadar ağzını açarak hakkı olan bir porsiyon lapa yemeğini talep ederek tüm Hristiyan alemine haykırıyordu... Sahibi ise, aksine tıpkı bir ölü gibi suskundu (Averçenko, 2017, s. 211).

Bir önceki parça ile bağlantılı olan 3. örnekte ise yazar aslında yaşamını yitirmiş olan kişinin “ölü gibi” ifadesiyle bulunduğu durumu daha da pekiştirmekte, üstü kapalı olarak da susan bir halkın üzerine ölü toprağının düştügünü, susmak eylemi ile hareketsiz olma, pasif kalma, yaşamdan kopma anlamlarını kuvvetlendirmektedir.

4) И только внизу, у самой панели, как ажурные кружева из-под юбки развратницы, как дессу кафешантанной блудницы, - виднеется грязно-белая пена большевистских декретов, постановлений, воззваний и заклинаний обожравшейся, издыхающей гадины (Averçenko, 1992, s. 329). Çev.: Bir tek aşağıda, kaldırımın hemen orada, kafeşantanlardaki kadınların iç çamaşırı, etek altındaki ajur danteller gibi asılı duran, Bolşeviklerin pislikle kirlenmiş, kötü kokan kararnameleri, talimatları, duyuruları, akan beyaz köpüklü salyalar gibi görünmekteydi (Averçenko, 2017, s. 254).

Yazar eserinin son bölümünde yer alan buradaki benzetmesinde Petersburg şehrinin devrimle nasıl değiştiğini, duvarların üzerindeki afiş, ilan, beyanname gibi yazıların şeh- 
rin görüntüsünü ne kadar çirkin bir hale getirdiğini tasvir etmektedir. Bunu yaparken de yazar ucuzluk anlamının çağrışımını kafeşantan gibi eğlence merkezlerindeki kadınların iç çamaşırları ile bu görüntüye kayıtsız kalamayan ağzından salyalar fışkıran erkeklerin görüntüsü ile özdeşleştirmektedir.

5) - Да вы не то говорите! Я спрашиваю, что бы вы сделали, если бы Троцкий попался вам в руки? - Боюсь, что в бою, в этой суматохе я пристрелил бы его, как бешеную собаку. - Ну, да - мы это понимаем; а если бы он без боя очутился в ваших руках? Глаза офицера сверкнули и засветились, как две свечки. - Так я бы его тогда, подлеца, в суд! (...). Какое странное время; у штатских такая масса воинственной кровожадности, а военные рассуждают, как штатские! (Averçenko, 1992, s. 310). Çev.: Ne anlatıyorsunuz siz? Ben size Troçki elinize düşse ne yapardınız diye soruyorum! - Korkarım, bu çılgın savaşın ortasındaki kudurmuş bir köpek gibi onu vururdum. - Anlıyoruz, peki ya savaş olmadan elinize düşmüş olsaydı? Subayın gözleri iki mum gibi ışıldayarak parladı. - O zaman o haini, mahkemeye çıkartırdım! (...). Ne kadar da garip bir zamandayız: siviller asker, askerler ise siviller gibi yargiliyorlar (Averçenko, 2017, s. 226).

Yazarın burada kullandığ benzetmelerden ilk ikisinin metinde bir önceki ifadeyi kuvvetlendirme, pekiştirme anlamlarının olduğu görülebilir: kuduz bir köpek gibi ve iki mum gibi. Son ifadedeki bu örneklendirmenin yanı sıra, aslında örneklendirmenin altında yatan anlama bakılacak olursa burada iki temel noktaya değinilebilir. Bunlardan ilki, "siviller asker askerler ise siviller gibi yargilıyorlar" ifadesinde her anlamda alt üst olmuş bir düzenin ortaya konarak vurgulandığıdır. İkinci olarak ise, sıradan insanların Devrimi yapanlara karşı öç, nefret ve kin duygularıyla nasıl insani duygularını yitirdikleri, Devrim'in sorumlularını öldürmek üzerine nasıl acımasızca eleştiriler yapıldığına dikkat çekilmektedir.

6) В тысяча девятьсот таком-то году большевики наконец завоевали всю Россию. Вне их власти остался только Крым, который и висел небольшим привеском на неизмеримом пространстве холодной и голодной Совдепии, как болтается несъедобный золотой брелок на огромном брюхе голодного, отощавшего людоеда (Averçenko, 1992: 289). Çev.: Bin dokuz yüz bilmem kaç yılında Bolşevikler nihayetinde tüm Rusya'yı ele geçirdi. Soğuk ve doymak bilmez Sovyetlerin uçsuz bucaksız alanında ufak bir uzantı gibi duran ve hakimiyet altına alınamayan tek yer olan Kırım, aç, bir deri bir kemik kalmış insan yiyicinin koca karnında sallanan yenmez altın bir zincir misali, tek başına kalakalmıştı (Averçenko, 2017, s. 193).

Kırım, Kızıl Ordu'nun ele geçirdiği son toprak parçasıdır. Yazar, Kırımı ele geçiren gücü tasvir ederken, Bolşevik yönetimini ele geçirdikleri topraklara rağmen, doymak bilmez bir istekle son kalan kara parçasını da himayesi altına almak isteyen bir canavara benzetmektedir. Yazar, Kızıl Ordu'nun her yeri ele geçirme isteğini ve bu anlamdaki doyumsuzluğunu "aç ve bir deri bir kemik kalmış" ifadesi ile dokundurma yaparak "insan yiyici” tabiri ile de Bolşevik yönetimini bir nevi yamyama benzetmektedir. Rusya'nın 
işgal altındaki toprakları arasında Kırımı tasvir ederken onu altın bir zincire benzetmesi ise, yazarın bakış açısıyla buranın aslında kendisi için ne kadar değerli bir yere sahip olduğunu vurgulamaktadır zira Kırım toprakları yazarın doğup büyüdüğü, 16 yaşına kadar yaşadığ1 ve son olarak 13 Kasım 1920’de buradan göç ettiği yerdir. Bunun yanı sıra yazar, Rusya'nın genel görünümünü “soğuk ve aç Sovyetler” şeklinde tanımlayarak, bu görüntüye uymayan değerli güzellikteki Kırım’1 “altın bir zincir” gibi tasvir etmektedir.

7) С грохотом, стоном и визгом понесется с теплого юга на холодный север огромная железная птица, дымящая и пыхтящая с натуги, понесется, как бешеная, на север - вопреки инстинкту других птиц, которые на зиму глядя тянутся не с юга на север, а с севера на юг. И будет чрево той птицы, этой первой ласточки, которая сделает весну, набито битком разным русским людом, взор которого, как магнитная стрелка, обратится к северу, а на лице напишется одна мысль, звучащая в такт лязгу колес: “Что там? Что там? Что там?” (Averçenko, 1992, s. 327). Çev.: Kasılmaktan dumanlar çıkaran, kabaran devasa büyüklükte demirden bir kuş, kışı görüp de güneyden kuzeye değil de kuzeyden güneye göçmek isteyen kuşların içgüdülerinin aksine, 1lık güneyden soğuk kuzeye çılgınlar gibi ilerliyordu. İlkbaharın habercisi bu ilk kuşun karnı ağzına kadar çeşitli Rus insanıyla dolu, bakışları bir pusula ibresi gibi kuzeye çevirili olacak; yüzünde ise, tıpkı dönen bir tekerleğin ardı ardı ardına çıkardığı: "Ne var orada?", "Ne var orada?", "Ne var orada?" ritmik sesi gibi tek bir düşünce belirecekti...(Averçenko, 2017, s. 252).

Buradaki benzetmede yazar sürgüne gönderilen, topraklarından ayrılan, tutuklanan insanların içinde bulunduğu treni, bir kuşa benzeterek cansız bir varlığa canlı bir varlığın özelliklerini yüklemektedir. Çılgın gibi benzetmesi ile anlatımını güçlendiren yazar, trenin vagonlarında birikmiş insanların bulunduğu yeri içi ağzına kadar dolu bir kuşun karnına benzetmektedir.

8) А вот теперь мы все, все наше русское огромное сердце, почуяли этот час ликвидации и расчета, и скоро, скоро грянет грозное, как звон тысячи колоколов, как рев тысячи пушек: «Бьет двенадцатый час! К расчету!» (Averçenko, 1992, s. 327). Çev.: Şimdiyse hepimiz, tüm kocaman Rus yüreğimiz tasfiye ve hesaplaşma saatini hissetmiştik ve çok ama çok yakın bir zamanda, tıpkı çalan binlerce çan, binlerce topçu silahından çıkan ses gibi, tehditkar bir şeyler yaklaşmaktaydı: "Saat on ikiyi vurdu! Hesaplaşmaya!” (Averçenko, 2017, s. 252).

\section{Sonuç}

Böylece bir eserin dili, eserin dönemi, eserde yer alan kahramanların kimliği, eserde ele alınan sosyal durum, toplumsal gelişmeler hepsi yazarın ustalıkla ortaya koyduğu üslupla çok şey anlatabilmektedir. Yazarın toplumun kültürüne mal olmuş öğeleri de kullanarak okuyucuda çağrıştırmayı hedeflediği düşünceleri belirli anlamlar taşıyan sembolik kelimelerle aktarması, tek bir dil öğesinin ne kadar çok anlama sahip olabileceğini ortaya koymadaki ustalığını sergilemektedir. Eserinde kullandığı semboller ile bu hedefine 
ulaşan yazar, kullandığı söz sanatlarıyla da anlatımını güçlendirmekte, üslubuna ince bir mizah katmaktadır. Bunun yanı sıra eserde kullanılan semboller, bir toplumun kültürüne dair pek çok öğeyi de içerisinde barındırabilmektedir. Farklı kültürlerde yer alan sembollerin çeşitli toplumlarca nasıl yer ettiklerinin irdelenmesi de toplumların sosyal ve tarihsel gelişimlerinin gözlemlenebilmesi, dilsel dünya görüşünün anlaşılması açısından da ilgi çekicidir. Tıpkı "elma" imgesinin kimi kültürlerde gençlik, iyilik, güzellik sembolü olarak görülürken, kimi kültürlerde felaketin, kötülügü̈n sembolü olarak görülebildiği gibi. Yazar için elma imgesi felaketin sembolü olarak ele alınmıştır. Yazarın söz konusu imgeleye yüklediği bu anlamı, Beyaz Ordu mensupları ve yanlılarının "eh elmacık nereye gidiyorsun, Kızılların eline düşer de geri gelemezsin" şeklinde dile getirilen şark1 ile özdeşleştirerek elma imgesinin geri dönüşü olmayan, tehlikeli ve ölümcül bir yolun göstergesi olduğu belirtilmektedir. Horoz imgesi ise, yazarın eserinde iyiliği sembolize etmek için kullandığı bir imge olarak karşımıza çıkmaktadır. Yazar Rusya'daki horoz imgesini diğer ülkelerdeki horozlar ile karşılaştırarak onu ayrı tutmakta, "aydınlığın, ışı̆̆ıln, güneşin ve sevincin habercisi” olarak tasvir ettiği horozu ve sesi ile, Rusya'y1 eski günlerine geri döndürecek ve kurtuluşuna ön ayak olacak olan Beyaz Ordu'ya işaret etmektedir. Devrim imgesini ve devrimin destekçilerini ise kötülüğün sembolü olarak aktaran yazar bunun için insan dışı varlıkları kullanmaktadır. Böylelikle, kötülüğün temsilcilisi olarak gördüğü Kızıl Ordu mensuplarını ve yanlılarını dünya dışından olan varlıklarla özdeşleştirerek gerçek dünyanın dışından olan ve ülke ve insanları için alışılmadık olan her şeyin ülkenin kendisi için kötü olduğunu vurgulamaktadır.

A. Averçenko'nun tropeleri sıklıkla kullandığı ve bunu da bilhassa anlatımı zengin kılmaktan ziyade güçlü kılmak için yaptığı ve böylece ifadelerini daha da etkili kıldığı gözlemlenebilmektedir. Yazarın söz sanatlarından karşılaştırma yoluyla benzetme öğesini sıklıkla kullanması ve bunu da canlandırma sanatı ile desteklemesi, eserin esas özünü oluşturan düşünceyi ya da eserde yer alan bir kavramı daha anlaşılır hale getirmek içindir. Yazar, varlıklar arasındaki benzerlik ve karşıtlıklardan yararlanarak ifade gücünü zenginleştirip düşüncelerini pekiştirip anlatımını güçlendirerek belirli bir yarg1ya varmaktadır. Benzetmeler yardımıyla vardığı bu yargılarla ise yazar, okuyucusunun kendisini daha iyi "hissedebilmesini" yani anlayabilmesini arzulamakta, benzeri retorik figürler de okuyucunun yazarı daha iyi anlamasına yardımcı olmaktadır.

\section{Notlar}

1 Rus halk hikâyelerinden “Петушок Золотой гребешок” (Altın İbikli Horoz), “Лиса и петух” (Tilki ve Horoz), “Kom, nетух и лиса” (Kedi, Horoz ve Tilki). Bkz. A.N. Afanaseva, Narodnıe russkie skazki (1983). Leningrad: Lenizdat.

2 Rus halk hikâyelerinden “Лиса, заяи, петух, медведь и петух” (Tilki, tavşan, ay1 ve horoz), "Петух и жерновиьь” (Tavuk ve değirmentaşı). Bkz. A.N. Afanaseva, Narodnıe russkie skazki (1983). Leningrad: Lenizdat.

3 N. Gogol'ün “Вий” (Viy); A.İ. Kuprin'in “Золотой Петух” (Altın Horoz), M. Bulgakov’un “Macmep u Mapzapuma” (Usta ve Margarita) adlı eserlerde horozun ötüşünden sonra etraftaki kötü 
güçler dağılıp kaçışmaktadır.

4 Rus kaynakları Rusya iç savaşının tarihini genel olarak 1918-1922 tarihleri arasında verirken, diğer yabancı kaynaklar ise bu tarihleri 1917-1922 veya 1918-1923 şeklinde vermektedir.

5 Yabloçko.Ensiklopediya.(17.02.2017)http://oiliv.ru/wiki/\%D0\%AF\%D0\%B1\%D0\%BB\%D0\%BE\% D1\%87\%D0\%BA\%D0\%BE

\section{Kaynaklar}

Averçenko, A. (1992). Zapiski prostoduşnogo: Neçistaya sila. Moskva: Kniga i biznes.

Averçenko, A. (2017). Bir safin notları (Çev. Leyla Çiğdem Dalkılıç). İstanbul: Doruk.

Aytaç, G. (1990). Genel edebiyat bilimi. Ankara: Say.

Bally, Ş. (2001). Frantsuzkaya stilistika. Moskva: Editorial.

Bulgakov, M. (2009). Master i Margarita. St. Petersburg: Azbuka klassika.

Çoban, A. (2004). Edebiyatta üslup üzerine. Ankara.

Durmuş, M. (2011). İmge-sembol kavramlarını yorumlama projesi ve Melih Cevdet Anday şiirinde imge. Turkish Studies - International Periodical For The Languages, Literature and History of Turkish or Turkic. Volume 6/3: 745-762.

Dobrinina M.V. (2005). Rol simvola v osvoenii smislovoy strukturı hudojestvennogo teksta. Avtoref. dis...kand. filol. nauk. Tver, s. 19.

Gogol, N. (2009). Polnoe sobranie soçineniy odnom tome. Moskva: Alfa-kniga.

Kirillina O.M. (2011). Russkaya literatura: teoretiçeskie i istoriçeskie aspektı. Moskva: Flinta: Nauka, 2011.

Kojina M.N., Duskaeva L.R., Salimosvky V.A. (2014). Stilistika russkogo yazıka. Moskva: Flinta, Nauka.

Kolesov V.V., Kolesova D.V. ve Haritonov A.A. (2014). Slovar russkoy mentalnosti v 2 tomah: $P$-Ya. St. Petersburg: Zlatoust.

Kuçeryavıh Yu. N. (2018). Strukturno-semantiçeskie osobennosti organizatsii ironiçeskoy otsenoçnosti i ee preprezentatsiya v proze A.T. Averçenko. World science: problems and innovations. Sbornik statey XX mejdunarodnoy nauçno-praktiçeskoy konferentsii: v 2 çastyah. Moskva: Nauka: Prosveşenie.

Levitskiy D.A. (1999). Jizn i tvorçeskiy put Arkadiya Averçenko. Moskva: Russkiy put.

Ünlüaycıl N. (2003). Grotesk anlatım ve Türk oyun yazarlı̆̆ında kullanımı. AÜ, DTCF Tiyatro Araştırmaları Dergisi: 68-84.

Rozental D.E. (2011). Spravoçnik po russkomu yazıku. Praktiçeskaya stilistika. Moskva: Mir i obrazovaine.

Tekin, M. (2002). Roman sanatı. İstanbul: Ötüken Neşriyat.

Vinokur, G.O. (1959). O zadachah istorii yazıka // İzbrannı rabotı po russkomu yazıku. Moskva: Uçpedgiz.

Elektronik Kaynaklar

İsa Mesih: Yol, Hakikat, yaşam. Petrus'un inkârı. (126. bölüm). Matta 26:69-75, Markos 14: 6672, Luka 22: 54-62, Yuhanna 18:15, 25-27. (erişim tarihi 10.07.2017).https://www.jw.org/tr/ yayinlar/kitaplar/isa-mesih/son-hizmet/petrus-isayi-inkar-eder/ 
